\title{
DESIGNING CONTENT FOR A WEB-BASED APPLICATION USED IN BLENDED COMPOSITION CLASSES: THINGS TO CONSIDER IN THE EFL/ESL CONTEXT
}

\author{
Irfan Rifai \\ English Departement, Faculty of Humanities, BINUS University \\ Jln. Kemanggisan Ilir III No.45, Kemanggisan - Palmerah, Jakarta 11480 \\ irifai@binus.edu
}

\begin{abstract}
In the world of composition teaching, teachers of writing play just as vital role. Their tasks are demonstrating, motivating, supporting, responding, and evaluating. The days of these teachers are often filled with editing and additional feedback sessions. Thus, in order to have a web especially designed as a tool for learning to write in ESL, the five tasks mentioned by Harmer should be made as important points to consider (teachers' preferences). The content of such web should be also based on careful considerations that include factors like students' preferences (user experience). It is to make sure that the web being created meets the preference of the users. With the thoughts, two groups of students were gathered in a study involving two writing classes in which online technology being used as a platform for students and Instructor to exchange ideas, review and edit drafts, provide writing tips links and leave comments on others' pieces of writing. Students' online activities were observed and their feedback during group discussion was used as the base to construct the content of the web.
\end{abstract}

Keywords: web application, blended class, composition class, ESL/EFL

\begin{abstract}
ABSTRAK
Dalam pengajaran menulis, guru memainkan peran penting. Mereka meragakan, memotivasi, mendukung, menanggapi, dan mengevaluasi. Guru sering disibukkan dengan tugas editing dan sesi umpan balik tambahan. Dengan demikian, diperlukan web yang dirancang khusus sebagai alat untuk belajar menulis di ESL. Lima tugas dalam Harmer harus dibuat sebagai hal penting untuk dipertimbangkan (preferensi guru). Isi web tersebut harus dipertimbangkan secara hati-hati yang mencakup faktor, seperti preferensi siswa (pengalaman pengguna) untuk memastikan bahwa web yang dibuat memenuhi preferensi pengguna. Dengan pemikiran tersebut, dua kelompok siswa dikumpulkan dalam sebuah penelitian yang melibatkan dua kelas menulis yang menggunakan teknologi online sebagai platform untuk siswa dan instruktur. Mereka dapat bertukar ide, mereview dan mengedit draft, memberikan dan menulis link yang berupa tip, dan meninggalkan komentar untuk tulisan siswa lain. Aktivitas online mahasiswa diamati; dan umpan balik selama diskusi kelompok digunakan sebagai dasar untuk membangun konten web.
\end{abstract}

Kata kunci: aplikasi web, kelas campur, kelas menulis, ESL/EFL 


\section{INTRODUCTION}

In the past few decades, from primary to university levels, technology has become an inseparable part of learning and its use is evenly spread to various disciplines and contexts. In the context of foreign and second language learning, an immense number of researches have been conducted to analyze the phenomena, the cases or even the correlations between the successes of foreign language learning through technologies' integration.

Among many ESL—related studies are studies on writing/composition paedagogy. Recent studies on the area of research are related to online feedback and revision (Yang \& Meng, 2013; Seileek \& Akshaar, 2014), use of mobile application (Li \& Hegelheimer, 2013) and collaborative writing (Yeh, 2014). The research areas explored by the studies represent current trends on technology and language learning.

In conventional writing or composition classes, Harmer (2004) believes that there are five things that composition teachers must assume, which are demonstrating, motivating, supporting, responding, and evaluating. About those composition teachers who opt to involve technology in their teaching and the teachers' roles, Lamy and Hampel (2007) define that online writing instructor rule is largely being facilitator. However, this facilitating task, multiplies in different functions. These are the facilitating functions of an online writing instructor: first, as process facilitator, a teacher here is to provide a model, a pathway for students to follow; second, adviser-counselor; third, similar to what Harmer has mentioned, as assessor; fourth, as researcher; fifth, as content facilitator; sixth, as technology designer; and lastly, as manager-administrator.

Other than being supreme facilitator, once a composition teacher decides to use online learning platform, he must possess a set of skills. The following set of skills is highly required.

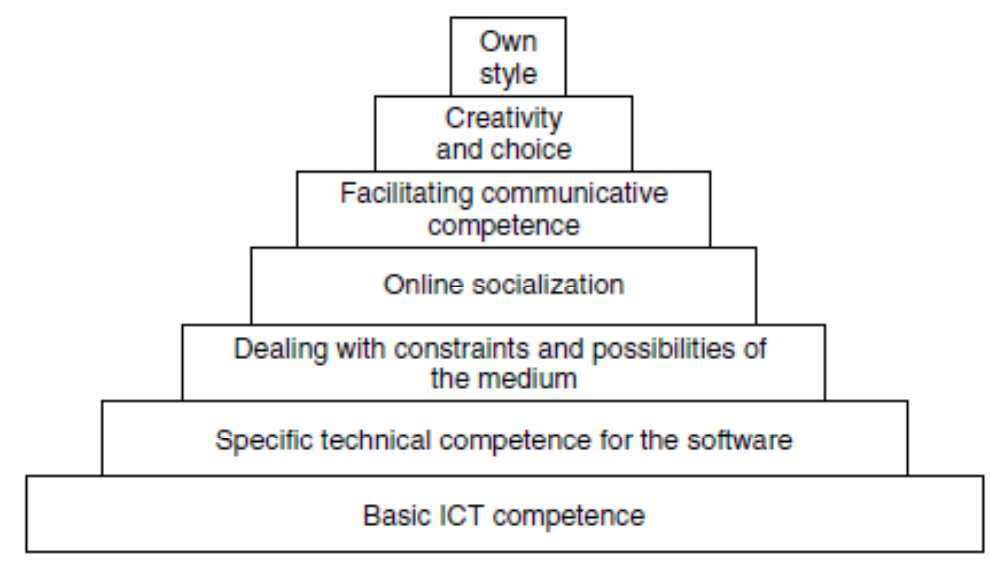

Figure 1 Basic skills for web-based class instructor

(Lamy \& Hampel, 2007)

In order to use a certain kind of webs, instructor needs to be aware of several points, as has been mentioned by Coffin \& Curry, et.al (2005). They are, first, authority issue: what organization sets the web; what the Author's qualifications are. Hence, it is very important for teachers to verify information. Second thing that teachers need to do is to examine the purpose of the page: whether it exists to inform, persuade, sell, or entertain. It is best that teachers look for potential bias. 
Recent study has shown that other than those considerations being mentioned, Miller (2005) suggests that web technology should focus on the user. In the web design world, these are the sort of questions that web designers should bear in mind. First, does the web support user task and goals? Second, does it acknowledge the strengths and the limitation of technology? For example, a good paper does not write somebody his paper. It should relieve him from the burden of dealing with fonts, margins, misspelled words, etc. Third, does it fit into the user's big picture, business constraints and Social issue? Fourth, does it perform well? And lastly, is it proven to be safe, accessible, and design friendly, as well as, fashionable?

In order to have a ready to use web for academic writing course, a case study is conducted and supported by a survey study. The purpose of this study was to explore: the usability of an online application through the experiences and the attitudes of the 64 users. The study also sought the explanation of students' process of accessing and synthesizing online information, drafting their writing, collaborating, and publishing their writing drafts. The data should be used as a model or base for web site development.

The study aimed to answer the following questions: how do students perceive the usability of yammer for its use in the academic writing class? From the experience of using Yammer, how would students identify their preferences for a website for academic writing? And how do students use the available online technology in producing an academic writing?

\section{METHOD}

It is a case study of two groups of students taking Academic Writing course in the even semester of 2013/2014. The two groups were introduced with Yammer, a Microsoft made online application, which was used as a means to help the classes with the writing process, i.e., brainstorming, drafting, publishing, reviewing and sharing ideas. The data gathered are students' experience-based opinions on the use of Yammer and their expectations for an online application to be used for academic writing course. Students' attitude and behavior during the use of the application were also explored. It was expected that certain themes emerged as patterns recognized when students were collaborating and exchanging ideas online. The methods of study can be seen in the Figure 1 below.
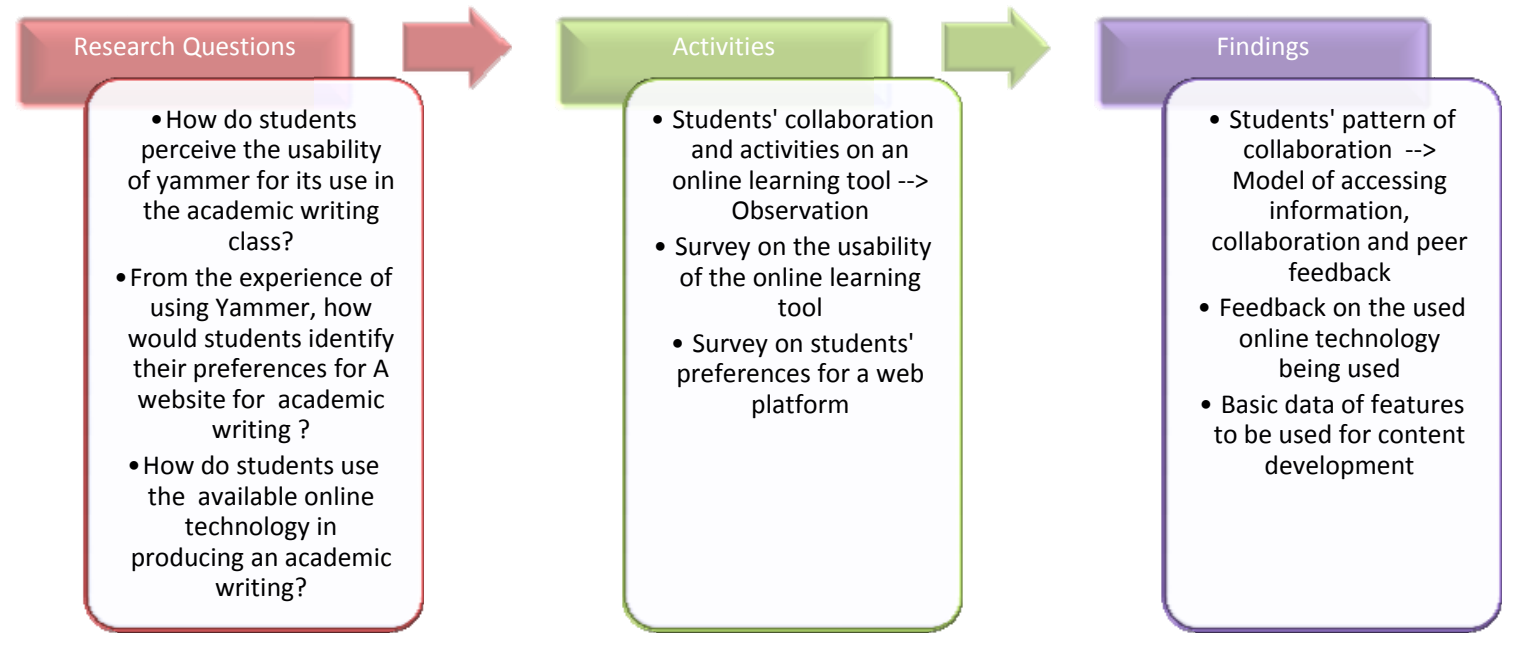

Figure 1 The Research Process 
The data were collected through survey and observation. In this case, researcher is involved directly as lecturer (participant). For the survey, out of 64 students becoming the members, 19 (30\%) responded to the survey. The small numbers of participants responding to the survey due to the lack of time provided for them to respond. Those who participated, however, are those who have been regularly active during online discussion. Thus, for such reason, their responses will be taken as real user experience responses.

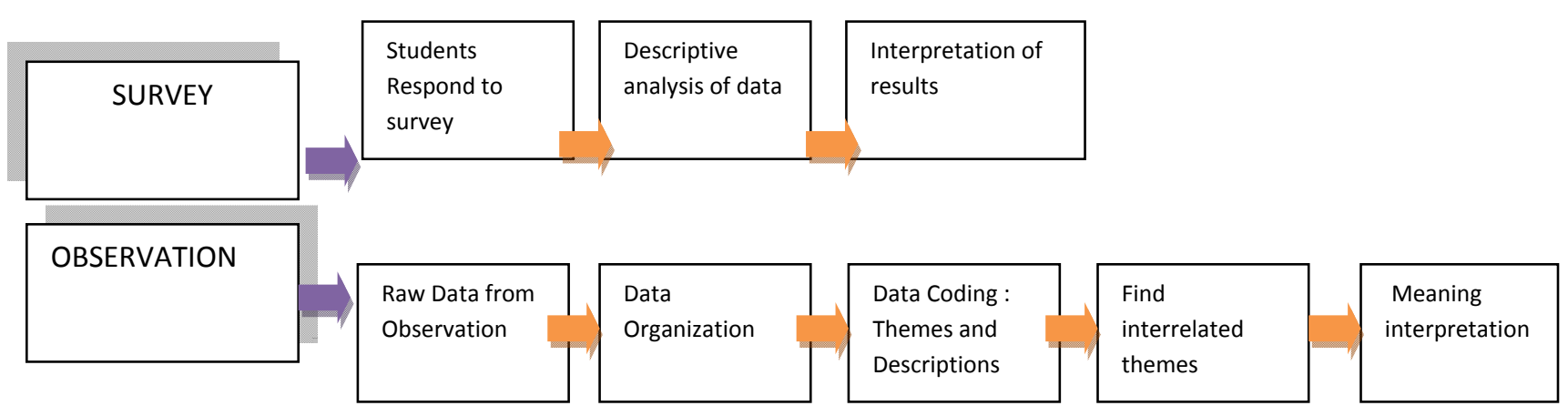

Figure 2 Data Collection Process

The researcher acted as lecturer (participant) during the 13 sessions, in which he observed the online interactions, collaboration and writing process steps done by students. The observation took place for 13 weeks. Notes were made during the time, organized and decoded to find similar themes and patterns.

\section{RESULTS AND DISCUSSION}

The first part of the survey, asks students' opinion on the usability of the online application that they have used for 13 sessions. The questions asked the students to rate from 1 (the least) to 5 (the most). The second part of the questions demanded students' open responses on Yammer. For the first part, the summary of the 19 responses of the questions can be summed up in the following table.

Table 1 Students’ experience on using Yammer

\begin{tabular}{|c|c|c|c|c|c|c|c|c|c|c|c|c|c|c|c|c|c|c|c|c|}
\hline \multirow[t]{2}{*}{ No } & \multirow[t]{2}{*}{ Question Items } & \multicolumn{19}{|c|}{ Students } \\
\hline & & 1 & 2 & 3 & 4 & 5 & 6 & 7 & 8 & 9 & 10 & 11 & 12 & 13 & 14 & 15 & 16 & 17 & 18 & 19 \\
\hline 1 & $\begin{array}{l}\text { I think that I would like to use this system } \\
\text { frequently. }\end{array}$ & 3 & 4 & 3 & 3 & 4 & 2 & 3 & 4 & 2 & 2 & 3 & 4 & 3 & 3 & 4 & 2 & 2 & 3 & 4 \\
\hline 2 & I found the system unnecessarily complex. & 2 & 2 & 4 & 2 & 2 & 3 & 2 & 2 & 3 & 3 & 2 & 2 & 4 & 2 & 2 & 3 & 3 & 2 & 2 \\
\hline 3 & I thought the system was easy to use. & 4 & 5 & 5 & 4 & 5 & 5 & 4 & 5 & 4 & 4 & 4 & 4 & 5 & 4 & 5 & 4 & 5 & 4 & 5 \\
\hline 4 & $\begin{array}{l}\text { I think that I would need the support of a technical } \\
\text { person to be able to use this system. }\end{array}$ & 1 & 2 & 2 & 1 & 1 & 2 & 1 & 1 & 2 & 5 & 1 & 2 & 2 & 1 & 1 & 2 & 2 & 1 & 1 \\
\hline 5 & $\begin{array}{l}\text { I found the various functions in this system were } \\
\text { well integrated. }\end{array}$ & 2 & 4 & 3 & 2 & 4 & 3 & 2 & 3 & 3 & 3 & 2 & 3 & 4 & 2 & 3 & 3 & 3 & 2 & 3 \\
\hline 6 & $\begin{array}{l}\text { I thought there was too much inconsistency in this } \\
\text { system. }\end{array}$ & 2 & 1 & 2 & 1 & 1 & 2 & 1 & 2 & 2 & 2 & 2 & 1 & 2 & 1 & 2 & 2 & 2 & 1 & 2 \\
\hline 7 & $\begin{array}{l}\text { I would imagine that most people would learn to } \\
\text { use this system very quickly. }\end{array}$ & 3 & 4 & 4 & 3 & 4 & 4 & 3 & 2 & 4 & 1 & 3 & 5 & 4 & 3 & 2 & 4 & 4 & 3 & 2 \\
\hline 8 & I found the system very burdensome to use. & 2 & 1 & 2 & 1 & 1 & 2 & 1 & 1 & 2 & 1 & 2 & 1 & 2 & 1 & 1 & 2 & 2 & 1 & 1 \\
\hline 9 & I felt very confident using the system. & 3 & 4 & 4 & 3 & 2 & 4 & 3 & 5 & 4 & 3 & 2 & 4 & 4 & 3 & 5 & 4 & 4 & 3 & 5 \\
\hline 10 & $\begin{array}{l}\text { I needed to learn a lot of things before I could get } \\
\text { going with this system }\end{array}$ & 1 & 2 & 3 & 1 & 3 & 3 & 1 & 2 & 3 & 4 & 1 & 1 & 3 & 1 & 2 & 3 & 3 & 1 & 2 \\
\hline
\end{tabular}


The average score of the responses for the first question is 3.5, which may mean that students are neither too enthusiastic nor ignorant about the application. The respondents responded positively to the uncomplexity of the application, with 2.5 in average believing that the application is not complex and 4.47 believing that it is easy to use. 1.1 in average even responding that they would need somebody else to help them operate the application. All in all, around 2.65 in average, respondents believe that they are comfortable with the application and in terms of usability, most would claim that yammer is relatively easy to use.

For the second part, students were asked to describe their opinions on the application by answering two open-ended questions. First, "Have you found the system to be useful / helpful for academic writing class? In what ways?" Then, the second question was, "Is there anything you would like to add or reduce about Yammer?" The answers are gathered in the following table.

Table 2 Summary of open ended questions

\begin{tabular}{|c|c|c|c|c|c|c|c|c|c|c|c|c|c|c|c|c|c|c|c|c|}
\hline \multirow[t]{2}{*}{ No } & \multirow[t]{2}{*}{ Responses } & \multicolumn{19}{|c|}{ Students } \\
\hline & & 1 & 2 & 3 & 4 & 5 & 6 & 7 & 8 & 9 & 10 & 11 & 12 & 13 & 14 & 15 & 16 & 17 & 18 & 19 \\
\hline \multirow[t]{3}{*}{ Q.1 } & $\begin{array}{l}\text { Kind of, because some classmates can } \\
\text { provide criticism to improve my writing }\end{array}$ & $\sqrt{ }$ & & & & & J & & & & J & J & & & & & & J & J & J \\
\hline & $\begin{array}{l}\text { Yes, I do. New knowledge and references. } \\
\text { Give and be given comments. }\end{array}$ & & J & $\checkmark$ & $\sqrt{ }$ & J & & J & & J & & & $\checkmark$ & & $\sqrt{ }$ & $\sqrt{ }$ & $\sqrt{ }$ & & & \\
\hline & No. & & & & & & & & $\checkmark$ & & & & & $\checkmark$ & & & & & & \\
\hline \multirow[t]{4}{*}{ Q.2 } & $\begin{array}{l}\text { Nothing, really -- it's already fine as it } \\
\text { is. }\end{array}$ & $\checkmark$ & & & & J & & J & $\sqrt{ }$ & & & & & & & & & J & & $\sqrt{ }$ \\
\hline & Reward for leaving comments & & $\checkmark$ & & & & & & & J & & & & & & $\sqrt{ }$ & & & & \\
\hline & Some multi media & & & $\sqrt{ }$ & J & & $\checkmark$ & & & & & J & $\sqrt{ }$ & J & & & J & & & \\
\hline & $\begin{array}{l}\text { Spell checker and auto mechanics } \\
\text { checkers }\end{array}$ & & & & & & & & & & J & & & & $\sqrt{ }$ & & & & J & \\
\hline
\end{tabular}

Of the three responses from Question One, 10 respondents (52\%) believe that they have learned more by using yammer and the fact that they can learn from one another. Four students (21\%), were somewhat hesitant. The four of them chose the phrase 'kind of' to describe their attainment during the class that uses yammer. Two students reacted negatively to the use of yammer. However, no explanation or elaborations were given.

There were four responses to Question Two. Asked whether they would have tips that may improve yammer, six students believe that Yammer is good as it is now and no further development necessary. Three students spoke of an interesting idea, which is to provide rewards to those who participate well kin he online discussions and feedbacks. The majority of the respondents, 7 out of 19, believe that the web would need videos and sounds to get students more interested. The last thing that the respondents mentioned are regarding spell checkers and other mechanics which might have been better if they are available and check students' mistakes automatically.

The last TWO parts of the survey asked students their opinions on the content of a good web used for academic writing course and its design. Since the questions ask students' preferences, the answers come in vary. On The Content part, the students answered like the following 
Table 3 Summary of Preferences Responses

\begin{tabular}{|c|c|c|}
\hline \multirow[t]{2}{*}{ Questions } & The content of the web should. . . & $\begin{array}{l}\text { 1. Have Tips on how to do 'academic writing' } \\
\text { properly } \rightarrow 9 \\
\text { 2. some examples of several academic essays, } \\
\text { advice from some experts, online group } \\
\text { discussion } \rightarrow 10\end{array}$ \\
\hline & I would prefer the web to be. .. & $\begin{array}{l}\text { 1. One like Yammer (collaboration oriented) } \\
\text { it's already good enough for us. Text } \\
\text { dominant one will be boring, and } \\
\text { multimedia dominant one will be too } \\
\text { distracting. } \rightarrow 11 \\
\text { 2. Dominant in Multi media } \rightarrow 5 \\
\text { 3. Texts- based } \rightarrow 3\end{array}$ \\
\hline
\end{tabular}

On the content part, 9 students expect to have practical tips on making academic writing, while 10 students expect to find examples of essay and advice from experts in multimedia format. A for their preferences on the layout, 11 out of 19 prefer to have a web like Yammer and 5 prefer a multimedia-based, while only 3 prefer text-based website/application.

How students use the available online technology in producing an academic writing, there are three main activities that students did while using Yammer. The first things that these students did were posting their draft and final work. In the 13 sessions within the academic writing course, students were expected to share 6 types of academic essays. 95 percents of the students managed to fulfill their obligations.

The next thing that students did was to ask and give for feedback for better drafts. At this stage, the participation rate was moderate with similar names were dominating the feedback times. In the middle of the semester, a special system was designed, in which a draft should be criticized by three students. The participation remained moderate. The number drafts reviewed by students also reflect the choice to whom they are comfortable with. The data shows that the majority of the students are still inclined to review their close friends, despite the instruction assigns otherwise.

Table 4 The frequency of reviews and who to review

\begin{tabular}{cccc}
\hline Students & How many times? & In Circle Friends & Out Circle freinds \\
\hline $\mathbf{1}$ & 5 & 4 & 1 \\
$\mathbf{2}$ & 4 & 2 & 2 \\
$\mathbf{3}$ & 6 & 4 & 2 \\
$\mathbf{4}$ & 7 & 3 & 4 \\
$\mathbf{5}$ & 3 & 3 & 0 \\
$\mathbf{6}$ & 2 & 2 & 0 \\
$\mathbf{7}$ & 1 & 1 & 0 \\
$\mathbf{8}$ & 0 & 0 & 0 \\
$\mathbf{9}$ & 5 & 3 & 2 \\
$\mathbf{1 0}$ & 7 & 5 & 2 \\
$\mathbf{1 1}$ & 3 & 3 & 0 \\
$\mathbf{1 2}$ & 2 & 2 & 0 \\
$\mathbf{1 3}$ & 1 & 1 & 0 \\
$\mathbf{1 4}$ & 4 & 3 & 1 \\
$\mathbf{1 5}$ & 0 & 0 & 0 \\
$\mathbf{1 6}$ & 0 & 0 & 0 \\
$\mathbf{1 7}$ & 1 & 1 & 0 \\
$\mathbf{1 8}$ & 1 & 1 & 0 \\
$\mathbf{1 9}$ & 2 & 2 & \\
\hline
\end{tabular}


The third thing that the students do online is sharing tips of academic features and links that support their academic writing performance. The majority of the links and tips, unfortunately, has come from the lecturer. However, most students claim that they really need such features on an online application.

\section{CONCLUSION}

The inclusion of Yammer as online supporting for learning tool was welcome by two groups of 64 students taking academic writing course, pretty enthusiastically. Students were not startled by such application, showing that they have been quiet exposed to various online applications that demand collaboration, critical thinking and synthesizing skills. On their assessment of the application, students rated Yammer pretty highly especially in the areas that it involves users' participations and potential collaborations. The study was not merely conducted on the objective of assessing Yammer as a tool, but was also intended to gather data for future web-based academic writing course.

\section{Suggestions}

Students expected that the future web would still make it possible for them to collaborate and have access to links of academic writing features, as well as multimedia and text to keep them engaged and well informed. The observation result shows that students require constant conditioning on their accessing the platform. It is suggested that writing/composition teachers be clear on the expected outcomes and the model of the online learning since the beginning of the course.

\section{REFERENCES}

Coffin, C. \& Curry, M. J., et. al. (2003). Teaching Academic Writing: A toolkit for higher education. Routledge: Taylor \& Francis Group.

Harmer, J. (2004). How to teach Writing. Pearson Education.

Lamy, M. N. \& Hampel, R. (2007). Online Communication in Language Learning and Teaching. New York: Palgrave Macmillan.

Li, Z \& Hegelheimer, V. (2013) Mobile-Assisted Grammar Exercises: Effects on Self-Editing in L2 Writing . Language Learning \& Technology, 17(3), 135-156.

Miller, J. (2005). The internet experience: user experience. IEEE Internet Computing, (05), 90- 92.

Seileek, A. \& Akshaar, A. (2014). Using peer computer-mediated corrective feedback to support EFL Learners’ Writing. Language Learning \& Technology, 18(1), 76-95.

Yang, Y. F. \& Meng, W. T. (2013). The effects of online feedback training on students' tex revision. Language Learning \& Technology, 17(2), 220-238.

Yeh, H. C. (2014). Exploring how collaborative dialogues facilitate synchronous collaborative writing. Language Learning \& Technology, 18(1), 23-37. 